\title{
Climate Change and its Impact on Agricultural Productivity in India
}

\author{
Rohitashw Kumar ${ }^{1 *}$ and Harender Raj Gautam ${ }^{2}$ \\ ${ }^{1}$ Division of Agricultural Engineering, Sher-e-Kashmir University of Agricultural Sciences and Technology of Kashmir, Srinagar (J\&K) -190025, India \\ ${ }^{2}$ Department of Plant Pathology and Mycology, Dr. Y.S. P University of Horticulture and Forestry, Nauni, Solan (HP) -173230, India
}

${ }^{*}$ Corresponding author: Rohitashw Kumar, Department of Agricultural Engineering, Sher-e-Kashmir University of Agricultural Sciences and Technology of Kashmir, Srinagar (J\&K) -190025, India, Tel:+91-94190052019; E-mail: rohituhf@rediffmail.com

Rec date: Feb06, 2014; Acc date: Apr01, 2014; Pub date: Apr10, 2014

Copyright: (C) 2014 Kumar R et al. This is an open-access article distributed under the terms of the Creative Commons Attribution License, which permits unrestricted use, distribution, and reproduction in any medium, provided the original author and source are credited.

\begin{abstract}
Climate change has a serious impact on the availability of various resources on the earth especially water, which sustains life on this planet. Changes in the biosphere, biodiversity and natural resources are adversely affecting human health and quality of life. Throughout the 21 stcentury, India is projected to experience warming above global level. India will also begin to experience more seasonal variation in temperature with more warming in the winters than summers. Longevity of heat waves across India has extended in recent years with warmer night temperatures and hotter days, and this trend is expected to continue. The average temperature change is predicted to be $2.33^{\circ} \mathrm{C}-4.78^{\circ} \mathrm{C}$ with a doubling in $\mathrm{CO} 2$ concentrations. These heat waves will lead to increased variability in summer monsoon precipitation, which will result in drastic effects on the agriculture sector in India. Climate models predict a gradual rise in carbon dioxide (CO2) concentration and temperature across the globe. These models, however, are not very precise in predicting future changes in local weather conditions. Local weather conditions such as rain, temperature, sunshine and wind, in combination with locally adapted plant varieties, cropping systems, and soil conditions can maximize food production as long as plant diseases can be controlled.
\end{abstract}

Keywords: Agriculture productivity; Climate change; Rainfall

\section{Introduction}

Agriculture production is directly dependent on climate change and weather. Possible changes in temperature, precipitation and $\mathrm{CO} 2$ concentration are expected to significantly impact crop growth. The overall impact of climate change on worldwide food production is considered to be low to moderate with successful adaptation and adequate irrigation [1]. Global agricultural production could be increased due to the doubling of $\mathrm{CO} 2$ fertilization effect. Agriculture will also be impacted due to climate changes imposed on water resources [2,3]. India will also begin to experience more seasonal variation in temperature with more warming in the winters than summers [4,5]. India has experienced 23 large scale droughts starting from 1891 to 2009 and the frequency of droughts is increasing. Climate change is posing a great threat to agriculture and food security. Water is the most critical agricultural input in India, as 55\% of the total cultivated areas do not have irrigation facilities.

Currently we are able to secure food supplies under these varying conditions. All climate models predict that there will be more extreme weather conditions, with more droughts, heavy rainfall and storms in agricultural production regions. Such extreme weather events will influence where and when diseases will occur, thereby imposing severe risks and potential crop failure. In developing countries like India, climate change is an additional burden since ecological and socioeconomic systems already face pressures from rapid population, industrialization and economic development. India's climate could become warmer under conditions of increased atmospheric carbon dioxide.

In India, average food consumption at present is $550 \mathrm{~g}$ per capita per day, whereas in China and USA are 980 and 2850 g, respectively
$[6,7]$. The country faces major challenges to increase its food production to the tune of $300 \mathrm{mt}$ by 2020 in order to feed its evergrowing population which is likely to reach 1.30 billion by the year 2020. To meet the demand for food from this increased population, the country's farmers need to produce $50 \%$ more grain by 2020 . The total gross irrigated area has more than quadrupled from 22.6 million ha in 1950-51 to 99.1 million ha in 2011-2012. Although, agriculture contributes $14 \%$ in the Gross Domestic Product (GDP) in India, $64 \%$ of the population depends on agriculture for their livelihood. Over the years, demand for water has increased due to urbanization, increasing population, rapid industrialization and other developmental initiatives. In addition, changes in cropping and land-use patterns, over-exploitation of groundwater and changes in irrigation and drainage have modified the hydrologic cycle in many climate regions and river basins of India. Availability of water is the most important factor in agricultural production. Water quality and quantity are serious constraints for agriculture in most parts of India. Agriculture must adapt to changing climatic conditions by tapping water resources and developing improved water management approaches. Simultaneously, there is also need to develop and implement technologies and policies which will help in reducing and mitigating greenhouse gas emissions. Therefore, assessment of the availability of water resources is future national requirement and expected impact of climate change and its variability is critical for relevant national and regional long-term development strategies for sustainable development.

India is home to $16 \%$ of the world population, but only $4 \%$ of the world water resources. Agriculture is directly dependent on climate, since temperature, sunlight and water are the main drivers of crop growth. While some aspects of climate change such as longer growing season and warmer temperatures may bring benefits in crop growth and yield, there will also be a range of adverse impacts due to reduced 
Page 2 of 3

water availability and more frequent extreme weather conditions. These impacts may put agricultural activities at significant risk. Climate change has already caused significant damage to our present crop profile and threatens to bring even more serious consequences in the future (WHO, 1992). Wheat yields are predicted to fall by $5-10 \%$ with every increase of $1^{\circ} \mathrm{C}$ and overall crop yields could decrease up to $30 \%$ in South Asia by the mid-21st century [8]. India could experience a $40 \%$ decline in agricultural productivity by the 2080s [9]. Rise in temperatures will affect wheat growing regions, placing hundreds of millions of people at the brink of chronic hunger [9].

In India, the growing population is a major concern, and there is a need to understand the availability of water in terms of increase in population growth. A decline has been projected in mean per capita annual freshwater availability and growth of population from 1951 to 2050 [6] is shown in Figure 1. The graph clearly indicates the 'twosided' effect on water resources as the rise in population will increase the demand for water leading to faster withdrawal of water and this in turn would reduce the recharging time of the water-tables.

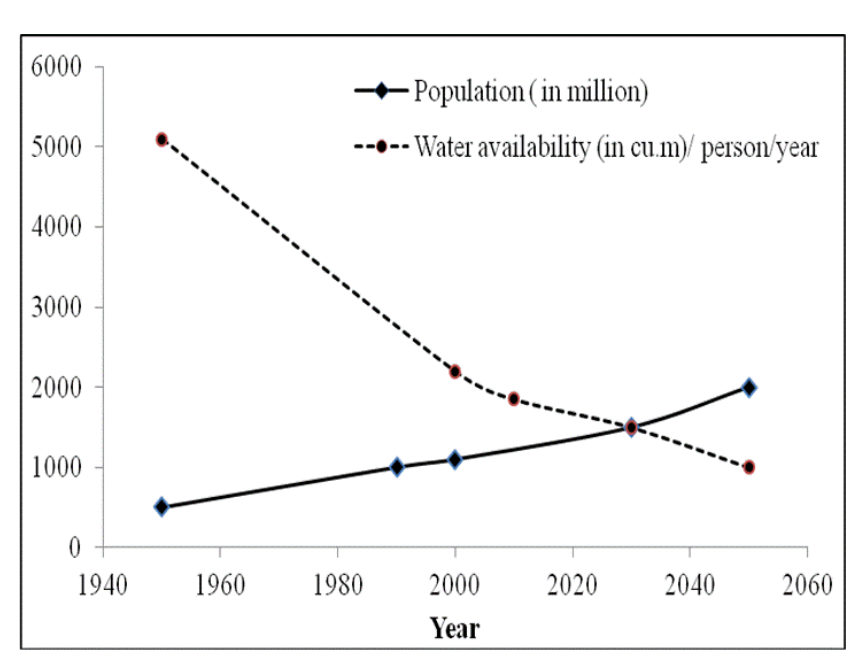

Figure 1: Observed and projected decline in per capita average annual freshwater availability and growth of population from 1951 to 2050

Indian agriculture consumes about $80-85 \%$ of the nation's available water[6]. The quantity of water required for agriculture has increased progressively through the years as more and more areas were brought under irrigation. Surface water and groundwater resources have played a significant role in irrigation and also in attaining self-sufficiency in food production during the past three decades. Availability of water from different sources and its utilization in the country has been shown in Table 1.

Availability and utilization patterns have been studied in India, and changes have been observed in surface temperature, rainfall, evaporation and extreme events since the beginning of the 20th century [6].

\section{Impact of Climate Change on Crop Productivity}

Rainfall in India has a direct relationship with the monsoons which originate from the Indian and Arabian Seas. A warmer climate will accelerate the hydrologic cycle, altering rainfall, magnitude and timing of run-off. Warm air holds more moisture and it will result in an increase in evaporation of surface moisture. Climate change has a direct impact on crop evapotranspiration (ET). In arid regions of Rajasthan state an increase of 14.8 per cent in total ET demand has been projected with increase in temperature [10]. The study further indicates that even a marginal increase in ET demand due to global warming would have a larger impact on the fragile water resources of arid zone ecosystem of Rajasthan [10]. Therefore, change in climate will affect the soil moisture, groundwater recharge, and frequency of flood or drought, and finally groundwater level in different areas [11-13]. Effect of climate change will affect water cycle [14]. In addition, rise in sea level will increase the risk of permanent or seasonal saline intrusion into ground water and rivers which will have an impact on quality of water and its potential use of domestic, agricultural and industrial uses. Climate change will have number of effects on agriculture [15].

\begin{tabular}{|l|l|}
\hline Particulars & Value \\
\hline Geographical area & 329 Mha \\
\hline Average rainfall & $120 \mathrm{~cm}$ \\
\hline Rainfall variation & $\begin{array}{l}100 \mathrm{~mm} \text { western most region to } 11000 \\
\text { eastern most region }\end{array}$ \\
\hline Annual precipitation & 4000 billion cu. m \\
\hline Available water resources & 1869 billion cu. m \\
\hline $\begin{array}{l}\text { Utilizable } \\
\text { Surface water(storage } \\
\text { diversion) } \\
\text { Groundwater (replenishable) }\end{array}$ & $\begin{array}{l}1122 \text { billion cu. m } \\
432\end{array}$ \\
\hline $\begin{array}{l}\text { Present utilization (surface } 63 \%, \\
\text { groundwater 37\%) } \\
\text { Irrigation } \\
\text { Domestic } \\
\text { Industry, energy and other uses }\end{array}$ & $\begin{array}{l}605 \text { billion cu. m } \\
501\end{array}$ \\
\hline $\begin{array}{l}\text { Per capita water availability } \\
74\end{array}$ \\
\hline
\end{tabular}

Table 1: Water resource in India at a glance [6,9].

Higher temperatures and changing precipitation patterns will severely affect the production patterns of different crops. Agricultural productivity will also be affected due to increased carbon dioxide in the atmosphere. All these changes will increase the vulnerability of the landless and the poor. Several recent analysis have concluded that the higher temperatures expected in coming years will disproportionately affect agriculture in the planet's lower latitudes where most of the world's poor live. In such a scenario, agriculture will need better management of natural resources like land, water and genetic resources to make it more resilient. India has made a National Action Plan on Climate Change which was unveiled in 2008. There are eight national missions that would form the core of the national plan. These include national missions for solar energy, enhanced energy efficiency, sustainable habitat, conserving water, sustaining the Himalayan ecosystem, a "Green India", sustainable agriculture and strategic knowledge platform for climate change. However, there are some innovative responses by water utilities to address these climate change risks and it has resulted in pushing the frontiers in a number of areas. It includes desalination, re-use and storm water harvesting and aquifer 
Citation: Kumar R, Gautam HR (2014) Climate Change and its Impact on Agricultural Productivity in India. J Climatol Weather Forecasting 2:

Page 3 of 3

recharge. It would be worthwhile to give high priority to "more crops per drop" approach, rainwater harvesting, aquifer recharge, revival of water bodies and conservation technologies. In the last decade, the Central Government has tried to address the issue through several initiatives such as subsidies for micro-irrigation (which optimizes water usage for agriculture), national watershed development project for rain fed areas and artificial recharge to ground water through dug wells in hard rock areas and rural water supply enhancement programmed through the catchment area approach.

In 2007, Union Ministry of Water Resources of the country initiated a Farmer Participatory Action Research Programmed in over 2000 villages all over the country to assess the impact of water saving technologies on agriculture production. It has been found that yield and income can be increased by 50 to 100 per cent in most of the crops by using water saving technologies. Additional yield of 1 ton per hectare can be realized through supplemental irrigation. Our agriculture is more prone to monsoon rains as we are growing high water requiring crops like rice and sugarcane. We should increase area under low water requiring but high value crops like pulses and oilseeds to counter the erratic monsoons.

\section{Conclusion}

Global climate change is not a new phenomenon. The effect of climate change poses many threats; one of the important consequences is bringing about changes in the quality and quantity water resources and crop productivity. It can be concluded that the Indian region is highly sensitive to climate change. Agriculture sector is the most prone sector as it will have a direct bearing on the living of 1.2 billion people. India has set a target of halving greenhouse gas emissions by 2050 [15]. There is an urgent need for coordinated efforts to strengthen the research to assess the impact of climate change on agriculture, forests, animal husbandry, aquatic life and other living beings.

\section{References}

1. IPCC (1998) Principles governing IPCC work, Approved at the 14th session of the IPCC.

2. Gautam HR, Kumar R (2007) Need for rainwater harvesting in agriculture. J Kurukshetra 55: 12-15.
3. Gautam H R (2009) Preserving the future. In; Joy of Life- The Mighty Aqua”. Bennett, Coleman \& Co. Ltd., The Times of India, Chandigarh.

4. Christensen JH, Hewitson B, Busuioc A, Chen A, Gao X, et al. (2007) Regional Climate Projections. In: Climate Change 2007: The Physical Science Basis. Cambridge University Press. Cambridge, United Kingdom.

5. Cruz RV, Harasawa H, Lal M, Wu S, Anokhin Y, et al. Asia. Climate Change 2007: Impacts, Adaptation and Vulnerability. Contribution of Working Group II to the Fourth Assessment Report of the Intergovernmental Panel on Climate Change. Cambridge University Press, Cambridge, UK.

6. Mall RK, Gupta A, Singh R, Singh RS, Rathore LS (2005) Water resources and climate change: An Indian perspective. Current Science 90: 1610-1626.

7. Mall RK, Singh R, Gupta A, Singh RS, Srinivasan G, et al. (2006) Impact of climate change on Indian agriculture: A review. Climate Change 78: 445-478.

8. IPCC (2001) Climate Change 2001: Impacts, Adaptation \& Vulnerability: Contribution of Working Group II to the Third Assessment Report of the IPCC. Cambridge University Press, Cambridge, UK.

9. IPCC (2007) Summary for Policy-makers, Climate Change 2007: Mitigation. Contribution of Working Group III to the Fourth Assessment Report of the IPCC. Cambridge University Press, Cambridge, United.

10. Goyal RK (2004) Sensitivity of evapotranspiration to global warming: a case study of arid zone of Rajasthan (India). Agric Water Manage 69: 1-11.

11. Huntington TG (2003) Climate warming could reduce runoff significantly in New England. Agric For Meteorol 117: 193-201.

12. Eckhardt K, Ulbrich U (2003) Potential impacts of climate change on groundwater recharge and streamflow in a central European low mountain range. J Hydrol 284: 244-252.

13. Allen DM, Mackie DC, Wei M (2004) Groundwater and climate change: a sensitivity analysis for the Grand Forks aquifer, southern British Columbia. Hydrogeol J 12: 270-290.

14. Xu J, Shrestha AB, Vaidya R, Eriksson M, Hewitt K (2007) The Melting Himalayas-Regional Challenges and Local Impacts of Climate Change on Mountain Ecosystems and Livelihoods. ICIMOD Technical Paper. International Centre for Integrated Mountain Development (ICIMOD), Kathmandu, Nepal.

15. Gautam HR, Sharma HL (2012) Environmental degradation, climate change and effect on agriculture. J Kurukshetra 60: 3-5. 